\title{
Correction to: Serum peptidome based biomarkers searching for monitoring minimal residual disease in adult acute lymphocytic leukemia
}

Ju Bai ${ }^{1}$, Aili He ${ }^{1 *}$, Chen Huang ${ }^{2}$, Juan Yang ${ }^{2}$, Wanggang Zhang ${ }^{1 *}$, Jianli Wang ${ }^{1}$, Yun Yang ${ }^{1}$, Pengyu Zhang ${ }^{1}$, Yang Zhang ${ }^{1}$ and Fuling Zhou ${ }^{1}$

Correction to: Proteome Sci (2014) 12:49

https://doi.org/10.1186/s12953-014-0049-y

Following publication of the original article [1], the authors reported an error in Fig. 9, the western-blot bands of PF4 were not correct.

The correct Fig. 9 is shown below.

\author{
Author details \\ 'Department of Hematology, Second Affiliated Hospital, Medical School of \\ Xi'an Jiaotong University, Xi'an 710004, Shaanxi Province, China. ${ }^{2}$ Department \\ of Genetics and Molecular Biology, Medical school of Xi'an Jiaotong \\ University/Key Laboratory of Environment and Disease-Related Gene, Ministry \\ of Education, Xi'an 710061, Shaanxi, China.
}

Published online: 24 October 2020

\section{Reference}

1. Bai J, He A, Huang C, et al. Serum peptidome based biomarkers searching for monitoring minimal residual disease in adult acute lymphocytic leukemia. Proteome Sci. 2014;12:49. https://doi.org/10.1186/s12953-014-0049-y.

The original article can be found online at https://doi.org/10.1186/s12953014-0049-y.

*Correspondence: heaili@mail.xjtu.edu.cn; zhangwanggang2003@yahoo.com 'Department of Hematology, Second Affiliated Hospital, Medical School of Xi'an Jiaotong University, Xi'an 710004, Shaanxi Province, China

Full list of author information is available at the end of the article

(c) The Author(s). 2020 Open Access This article is licensed under a Creative Commons Attribution 4.0 International License, which permits use, sharing, adaptation, distribution and reproduction in any medium or format, as long as you give appropriate credit to the original author(s) and the source, provide a link to the Creative Commons licence, and indicate if changes were made. The images or other third party material in this article are included in the article's Creative Commons licence, unless indicated otherwise in a credit line to the material. If material is not included in the article's Creative Commons licence and your intended use is not permitted by statutory regulation or exceeds the permitted use, you will need to obtain permission directly from the copyright holder. To view a copy of this licence, visit http://creativecommons.org/licenses/by/4.0/ The Creative Commons Public Domain Dedication waiver (http://creativecommons.org/publicdomain/zero/1.0/) applies to the data made available in this article, unless otherwise stated in a credit line to the data. 


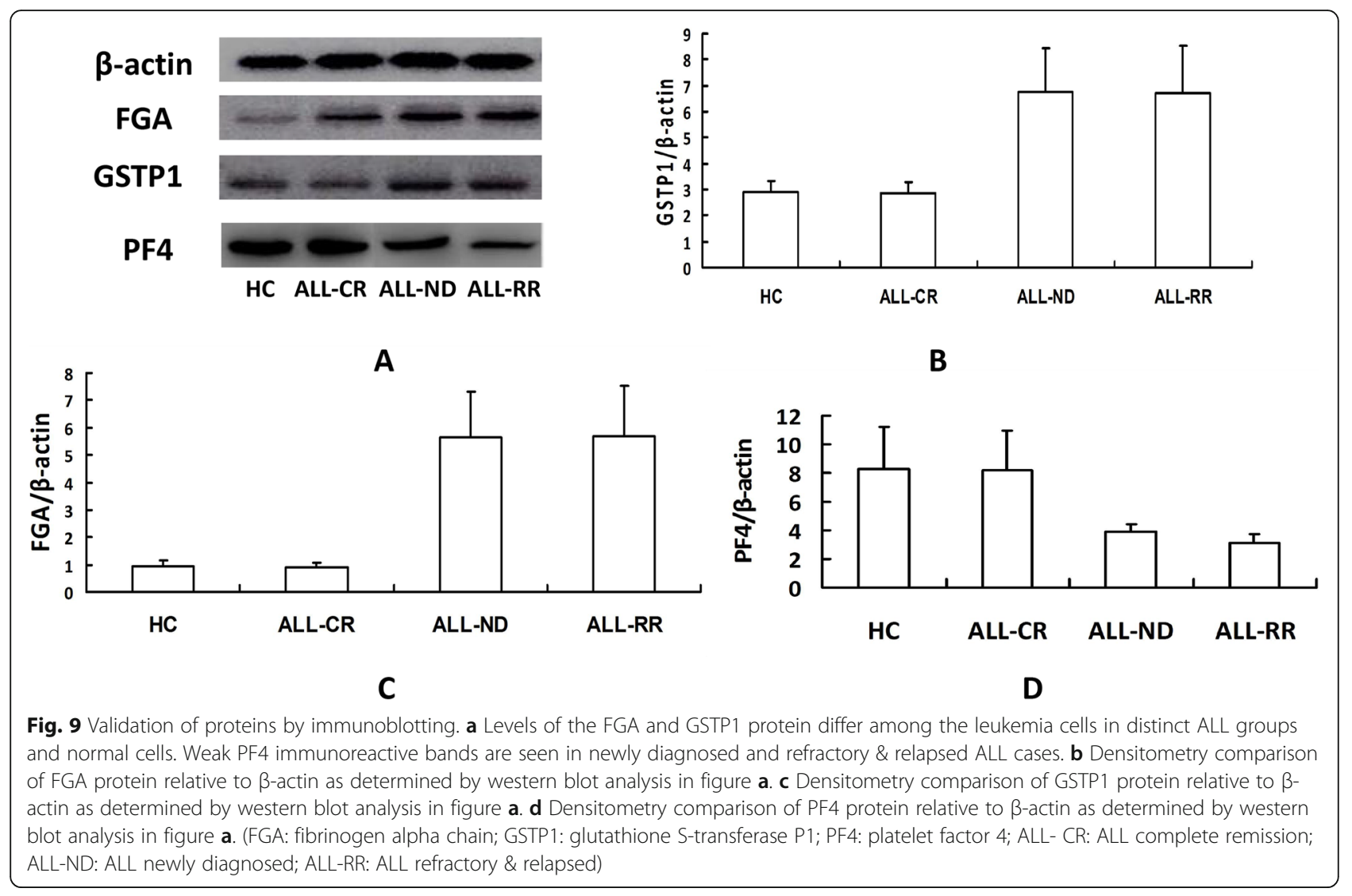

